\title{
8. Living standard potential and the transmission of advantage in Chile
}

Seymour Spilerman and Florencia Torche*

\section{INTRODUCTION}

Attempts to understand the determinants of living standards and family well-being have frequently been cast, in recent years, in an asset development framework. This is the case with studies pertaining to the capabilities and functionings of poor households (for example, Sen 1987, 1993; Oliver and Shapiro 1995; Shapiro 2001), although an asset perspective - as distinct from a focus on income flows - has also received attention in assessments of the economic circumstance of working- and middle-class families (Inhaber and Carroll 1992; Wolff 1995; Ackerman and Alstott 1999). An emphasis on asset development and asset holdings, moreover, is a common theme in the literatures on family welfare in both developed and lessdeveloped countries, although the particular asset that is stressed is often different in the two literatures.

In the United States the asset development literature has emphasized the accumulation of material resources: savings accounts, retirement funds, homes, and the like (Sherraden 1991; Edin 2001). As part of an antipoverty strategy, the goal of asset development formulations is to redirect welfare policy from a system of means-tested income supplements to a set of programs intended to reduce dependency and empower the poor to take responsibility for their lives. Current welfare policy is viewed as discouraging household savings and entrepreneurial activity, as well as future planning and investment calculations, since it makes the accumulation of even modest assets a reason for losing eligibility. Thus, the very behaviors and dispositions that are valued in middle-class culture and are central to the economic functioning of families, are discouraged for the poor population.

In most asset-building formulations, the goal of empowerment would be accomplished by promoting the accumulation of resources in the form of individual development accounts or IDAs (Sherraden 1991, 2001). Through the provision of matching funds, poor families would be encouraged to save from their income flows with more generous matching rates for 
the very poor, who would have greatest difficulty putting aside even modest amounts. ${ }^{1}$ These monies could be withdrawn only for targeted purposes to purchase a home, start a business, further the education of the account holder or a family member, or for retirement expenses. When not exhausted by these expenditures, the accounts could be inherited, which would provide some funds to the younger generation in a population that commonly receives little in the way of intergenerational transfers. An essential point is that the mere fact of asset holdings would be expected to stimulate the sorts of financial calculations and behaviors that are critical for economic independence.

In the United States, participation in asset development programs is also encouraged for the wider population. With the contraction of public transfer supports and the growing emphasis on private sector approaches to social welfare, families increasingly need to rely on their own resources to cover the costs of medical care, nursing-home stays, the education of children, and to provide retirement income. However, the asset holdings of the majority of Americans are modest, leaving many vulnerable to financial crisis in the event of illness or job loss. Wolff (2001, p. 63), for example, estimates that some 40 per cent of American families could subsist on their financial reserves for less than one month, even at a consumption level equal to 125 per cent of the poverty line.

In light of the importance of accumulating savings to protect future consumption needs, President Bill Clinton, in 1999, proposed a program of universal savings accounts (USAs), essentially a version of IDAs targeted more broadly than to the poor population. This would have been in addition to existing $401(\mathrm{k})$ plans and Keogh accounts, which already provide tax advantaged savings for middle-class families. Senator Bob Kerry has also proposed children's savings accounts (CSAs), in which annual deposits would be made by the federal government for all children from birth through age 18; Representative John Kasich has proposed retirement savings accounts (RSAs), intended as a supplement to Social Security retirement income. While none of the proposals reached fruition in the 106th Congress, the present attempt by the Bush administration to divert a portion of Social Security accumulations into private investment accounts very much fits with the spirit of this legislative agenda.

If the asset development literature in the United States, especially the version formulated for the wider population, emphasizes material resources intended as a store of future consumption, the parallel literature in lessdeveloped countries, especially in Latin America, identifies education and human capital as the assets of principal importance (Birdsall and Londono 1997; Attanasio and Szekely 2001). As such, this literature has adopted a broader view of assets, encompassing all potentially productive resources 
in a household: material assets, social capital, and human capital (Moser 1998). Also, when material assets are discussed it is the productive role of the asset that is stressed. Thus, while home ownership is valued in the asset literature of developed countries as a store of savings (consumption reserve), the parallel literature in less developed countries emphasizes the productive aspect of home ownership, namely the opportunity it accords a family to engage in domestic manufacturing or to open a storefront business in one of the rooms of the residence (Moser 1998).

\section{Comparing the Formulations}

One can speculate about the reasons for the difference in emphasis in the two literatures. First, the asset literature in the United States has become increasingly oriented to the well-being of the general population, stimulated by the press for privatization of welfare services and the insecurities that are attending this conversion. In Latin America, in contrast, the asset literature remains rooted in a concern about high and persistent poverty. ${ }^{2}$ Directed at this problem, the asset approach has been raised as an alternative to safety-net strategies for combating poverty, which are regarded as palliative and as not addressing the causes of indigence and vulnerability (Katzman et al. 1999).

A consideration of material assets also provides insight into a second pervasive problem in Latin America: inequality in household income. ${ }^{3}$ This has generally been explained by its immediate causes, especially the income generation potential of households through labor market participation. However, to the extent that material and financial assets play a role in labor market opportunity - facilitating the acquisition of a small business or entrance into the crafts and professions - or contribute directly to household income through investment returns, this heightens the importance of acquiring a detailed understanding of the distribution of various asset types in the population, as well as the mechanisms by which they are accumulated, utilized, and transferred. ${ }^{4}$

A second reason for the difference between the US and Latin American literatures is that the type of assets stressed in the United States - material and financial resources - are largely unavailable to the poor in Latin America. Financial assets are almost nonexistent in this population, and even access to formal credit or financial markets - in the form of credit cards, checking accounts, and small loans for productive purposes - is very limited (Mezzera 1993).

The most significant material asset in the United States, home ownership, has a very different status in Latin America. The majority of Latin American poor do not have access to government housing support. As a result, the poor use two housing strategies: illegal occupation of urban land with the self-construction of precarious residence units ${ }^{5}$ (whose market 
value is minimal), or, especially in the case of newly formed families, choosing to reside with a relative, usually a parent. Even in Latin American countries where state policies have been successful in reducing housing deficits among the poor (for example, Costa Rica and Chile), the market value of the government-provided units is low. The housing projects tend to be located in the urban periphery, distant from job sources, homogeneous in poor residents, and lacking in social services. Moreover, because the housing market for the poor is largely informal, legal title is often deficient (de Soto 2000). This reduces both the market value of a residence and the consequent ability to use home equity as collateral for bank loans. Thus, while home ownership may provide shelter for the poor, it does not constitute a vehicle for savings buildup, as it does in the United States.

Third, the focus on education and the acquisition of human capital stems from the problematic nature of access to schooling and the low likelihood of completion of even the lower grades of study. As compared to the United States and Western European countries, where access to secondary education is universal, the gross enrollment rate in secondary school reaches only 62 per cent in Latin America, with sharp variations across countries and income levels (UNESCO 1999). Education and human capital are critical determinants of a family's capability to function in a modern, industrial economy. Thus, in countries in which a large proportion of the population is undereducated, a central concern must be, of necessity, with strategies for enhancing school completion, especially in the primary and middle grades (Gallart 1998).

Fourth, the emphasis in Latin America on the productive over the consumption storage function of assets emerges from the strong association between poverty and labor market variables. Empirical studies show that the main determinants of poverty in Latin America are unemployment, number of household members in the labor force, and the low returns to labor market participation (ECLAC 2001, Ch. 1). Also, decomposition of poverty rates in terms of population characteristics reveals that occupational affiliation is a major factor explaining poverty (Attanasio and Szekely 1999). Awareness of the centrality of labor market variables in accounting for poverty rates has led to a focus on productive assets; that is, resources that facilitate labor market participation, such as capital to start a small business, a room for a workshop, family assistance for child care, and the like (Birdsall and Londono 1997).

\section{What Can Be Learned from the US Asset Literature?}

The asset literature in the United States is oriented to material resources because of the concern with fluctuations in the performance of the 
economy, which is addressed by the 'consumption reserve' aspect of asset holdings. This orientation is also relevant to Latin American countries, not only because economic fluctuations are deeper and more sudden in this region, but because the welfare and job security systems are more limited in their ability to effectively protect families from sharp income declines due to unemployment or health events (Marquez 2001; Mesa-Lago 2001). Thus, a broadening of the notion of household assets to include material and financial resources that function as a consumption reserve would illuminate the capabilities of families to withstand at least brief periods of job loss without descending into indigence.

Further, the focus in the United States on the 'consumption reserve' function of assets has brought attention to the role of parental resources and transfers of resources in the transmission of inequality across generations, a theme that has received little consideration in the asset literatures of Latin America or other less-developed countries. In the United States there has been considerable research, for example, into parental decision making with respect to inter vivos transfers versus bequests, parental motives in allocating transfers when there are several children, the sensitivity of parental support to the availability of public assistance programs, and the contribution of parental transfers to the wealth holdings and living standards of adult children (Kotlikoff and Summers 1981, 1988; Modigliani 1988; Holtz-Eakin and Smeeding 1994; McGarry and Schoeni 1995; Spilerman 2000).

While inequality of living standards is a matter of deep concern in Latin America, because the root cause is identified with low levels of human capital and poor labor market integration - and because the bulk of material asset holdings is concentrated in a small fraction of the population - little attention has been given to the role of parental resources as a factor in the economic well-being of families. Rather, the dominant conceptual model is one that emphasizes investments in health care, public education, and other sources of human capital as the avenue for enhancing the labor force productivity of the poor, presumably, in the process, bringing about a reduction of inequality in household income and in living standards (Altimir 1998; Aninat 2000).

This strategy, however, is based on two presumptions. First, it is assumed that low rates of school completion in poor households are a result of suboptimal access to schooling or a consequence of inadequate curricula or school facilities. While the contention of underinvestment in primary and secondary education in Latin America is not in dispute (for example, Birdsall et al. 1998; Gallart 1998), a related cause of low completion rates may well be the financial burden placed on a family from maintaining a teenage child in school, forgoing the income that would otherwise flow to the household 
from his or her employment. Indeed, Moser (1998) argues that one way lowincome households respond to economic crises is by increasing their reliance on child labor, presumably removing children from school.

This sort of problem is familiar to developmental economists (for example, Sen 1992; Solimano 2000) and relates to the formulations of moral philosophers in regard to distributive justice (Cohen 1993; Rawls 1999). A key issue in this literature is the impact of "morally arbitrary factors' - disadvantages in initial conditions, such as parental resources, that can curtail the ability of an individual to utilize the opportunities formally available to all. Thus, even if education is a universal right, effective access to schooling may depend critically on parental income and assets. While this conditioning of opportunity is well recognized (for example, Birdsall et al. 1998), little research has been carried out to explore the dimensions of the dependence of educational attainment and, ultimately, living standards on parental resources.

A second assumption relates to the type of inequality that is worrisome and the determinants of this form of inequality. The intent of raising the educational attainment of poor children and effecting a reduction in educational inequality is not the ultimate goal. Rather, what is problematic is the presence of great inequality in living standards. The implicit presumption behind public investments in schooling is that living standards are largely determined by educational attainment, translated into labor market rewards, rather than by parental advantage. Yet, in actuality, the extent to which parental resources influence the economic well-being of adult children is an empirical question, with the assessment likely to differ by country. In Israel, for example, parental assets are associated with early home ownership and with other dimensions of living standards: number of household durables, car ownership, frequency of household help. Moreover, this effect is net of the educational attainment and earnings of adult children, suggesting the importance of direct transfers of parental resources (Spilerman 2004).

Insight into the determinants of living standards in a country is essential to the formulation of effective policies for enhancing family welfare and weakening the linkage between parental advantage and life chances. If low educational attainment is primarily due to deficiencies in school availability, it would be sufficient to focus public resources on improving access to schools and enriching the educational experiences of children. However, to the extent that a lack of parental resources is a significant contributing factor, policies that channel income supports to poor parents, encourage asset building by families, or effectively reduce liquidity constraints, thereby permitting poor families to borrow against future earnings, would be indicated (Birdsall et al. 1998; Stallings et al. 2000). Similarly, to the 
degree that inequality is reproduced across generations by means of direct transfers of assets, it may be necessary to entertain redistribution policies such as gift and estate taxation or an effective progressive income tax structure, as well as programs that encourage asset accumulation.

The present study is an attempt to explore the preceding issues by examining the impact of parental assets on the educational attainments and financial well-being of the Chilean population. Chile is an interesting research site because it is a relatively urban, industrialized country, with a large wage-earning sector, in comparison with other states in Latin America. It is a country in which many social welfare programs, previously funded from public monies, have been privatized, leaving families increasingly dependent on their own resources and, where available, on the assets of relatives. For this reason parental asset holdings may well be consequential to the economic welfare of adult children. We hasten to add that while parental effects of this nature are commonly expected in wealthy families, it can be the case that even modest levels of parental assistance, when carefully targeted, have a considerable impact on the life chances and living standards of the wider population, as has been reported for Israel (Spilerman 2004).

In the next section, we review some of the salient features of the socioeconomic environment and the organization of the educational system in Chile. This material provides the background for the examination of parental resource effects on educational attainment, an analysis undertaken in the subsequent section. Following that investigation, we examine the impact of the parental variables on the earnings, household income, and wealth holdings of adult children - which we view as measures of the living standard capacity of a family.

\section{THE CHILEAN CONTEXT}

The Chilean economic landscape is significantly different from what it was 30 years ago. During the 1970s and 1980s the Chilean economy underwent a deep transformation, experiencing macroeconomic stabilization, trade and market liberalization, and the privatization of social services. The social welfare system, one of the most comprehensive and advanced in Latin America but also one that is segmented and underfunded, was reformed. The reform included reduction of the state role in public spending, as well as privatization, marketization, and decentralization in the sectors of health care, education, housing, social security, and pensions. Chile's economic performance, especially in the past 15 years, can be described as a 'success story'. After a deep economic recession in the early 
Table 8.1 Poverty rate in Chile, 1987-2000

\begin{tabular}{lrrrrrrr}
\hline & 1987 & 1990 & 1992 & 1994 & 1996 & 1998 & 2000 \\
\hline $\begin{array}{l}\text { Indigencel (extreme } \\
\quad 17.4\end{array}$ & 12.9 & 8.8 & 7.6 & 5.8 & 5.6 & 5.7 \\
$\begin{array}{l}\text { poverty) } \\
\text { Non-extreme poverty }\end{array}$ & 27.7 & 25.7 & 23.8 & 19.9 & 17.4 & 16.1 & 14.9 \\
Total poverty & 45.1 & 38.6 & 32.6 & 27.5 & 23.2 & 21.7 & 20.6 \\
\hline
\end{tabular}

Notes:

1. The indigence (extreme poverty) line is defined by the per capita monthly cost of a basic food basket. In year 2000 the urban indigence line was Chilean $\$ 20281$ /month (approx. US\$31), and the rural indigence line was Chilean \$15616/month (approx. US\$24).

2. The (total) poverty line in urban areas is twice the indigence line, and in rural areas it is 1.75 the indigence line. Households whose per capita income falls below the poverty line, but above the indigence line, are considered 'non-extreme' poor households.

Sources: CASEN Surveys (Ministry of Planning 2001a, 2002a).

1980s Chile has experienced sustained economic growth, with GDP per capita rising from US $\$ 2671$ in 1985 to US $\$ 5501$ in 1998 (Central Bank of Chile 2002; National Institute of Statistics 1998), an average annual increase of 5.5 per cent. This sustained growth has brought about a significant improvement in material living conditions and a reduction in poverty. As is evident in Table 8.1, total poverty declined from 45 to 21 per cent between 1987 and 2000, and indigence (extreme poverty) dropped from 17 to 5.7 per cent in the same period.

There is, however, a dark side to this success story, namely the continuation of very high inequality in the income distribution. After a worsening in the 1970s and 1980s, inequality improved slightly in the 1990s and has remained stable ever since. As can be seen from Table 8.2, the Gini coefficient was virtually the same in 1987 and 1998, and the ratio of the income shares received by the wealthiest and poorest quintiles remains fixed at about 15 . The only notable change is a small increase in the share received by the wealthiest 1 per cent of the population, which expanded from 12 to 13.2 per cent during the 1990 s.

Thus, in spite of the significant reduction in poverty, income inequality in Chile remains one of the highest in the world, surpassed in Latin America only by Brazil, Colombia, and Honduras (World Bank 2001, Ch. 3 ). Even though adjustments for in-kind and cash transfers to the poor reduce the Gini coefficient by about 0.05 points, the income distribution remains extremely concentrated. Economic growth has therefore led to a lessening of poverty without altering the distribution of income in the population; that is, relative living standards have remained constant. 
Table 8.2 Percentage distribution of income by quintile, and various inequality measures, Chile, 1987-2000

\begin{tabular}{lrrrrrrr}
\hline Income quintile & 1987 & 1990 & 1992 & 1994 & 1996 & 1998 & 2000 \\
\hline 1 (low) & 3.8 & 4.1 & 4.3 & 4.1 & 3.8 & 3.7 & 3.7 \\
2 & 7.6 & 8.1 & 8.3 & 8.1 & 8.0 & 8.0 & 8.2 \\
3 & 11.5 & 12.3 & 12.2 & 11.9 & 11.8 & 11.7 & 12.2 \\
4 & 19.1 & 18.1 & 18.5 & 18.6 & 19.2 & 19.2 & 18.4 \\
5 (high) & 58.0 & 57.4 & 56.7 & 57.3 & 57.2 & 57.4 & 57.5 \\
Total & 100.0 & 100.0 & 100.0 & 100.0 & 100.0 & 100.0 & 100.0 \\
\hline Ratio Q5/Q1 & 15.3 & 13.8 & 13.1 & 14.0 & 14.8 & 15.5 & 15.5 \\
Top 1 per cent & 12.0 & 12.4 & 13.7 & 12.4 & 12.7 & 13.2 & -2 \\
Gini & 0.547 & 0.532 & 0.536 & 0.529 & 0.541 & 0.547 & -2 \\
\hline
\end{tabular}

Notes:

1. Quintile distribution based on income specification which includes labor market earnings, self-production, fringe benefits, rents, interest, capital gains, social security income, and pensions.

2. Data not available.

Sources: Quintile distribution: CASEN Surveys (Ministry of Planning 2001b, 2002a), top 1 per cent and Gini coefficients: World Bank (2001, Ch. 3).

Empirical studies have shown that the main determinants of poverty and inequality are household composition, years of schooling, and the different returns to schooling levels, in regard to employment rates and earnings (Larranaga and Raczinski 1995; Bravo and Contreras 1999; Contreras and Larranaga 1999; World Bank 2001, Ch. 2). Based on these findings the prevalent causal argument is the following: education determines the formation of human capital, which influences labor market participation, ultimately accounting for living standards. In the framework of this argument it is reasonable to focus on education and human capital as the generative assets. However, the disassociation between the time trends in poverty and inequality suggests that there may be other assets, differentially available to the populations at different income levels, which play a significant role in the maintenance of inequality. This could come about through two mechanisms: the contribution of material resources to the formation and utilization of human capital, and income returns to the household from investments in financial instruments. In either case, direct asset transfers across generations would contribute to the buildup of these resources and to household income flows.

In order to understand the role of parental assets in the formation of 
human capital, we review the characteristics of the Chilean educational system. Chile has experienced a significant educational expansion during the second half of the twentieth century. Until the 1960s the expansion was focused on primary education, with enrollment exceeding 90 per cent by 1970. Secondary school enrollment was less than 20 per cent at the beginning of the $1960 \mathrm{~s}$, rose to 49 per cent of the 14-18 age group in 1970, and to 84 per cent in 2000 (Cox and Lemaitre 1999; Ministry of Planning 2002b).

Our best estimates of current educational attainment are summarized in Panel A of Table 8.3, in which we have calculated (from CASEN Survey 2000) enrollment and completion rates for each educational level. Age cohorts for assessing educational attainment were selected so that we can assume that the great majority in a cohort who would ever complete the educational level had recently done so by the year 2000: the 15-19 age cohort for primary school, the 20-24 cohort for secondary education, and the 25-29 for tertiary study. In Panel B we present enrollment and completion rates for the 25-29 age group, which best conveys the differentiation in educational attainment among the income quintiles of a single cohort that has recently completed its schooling.

From these data we note that by the year 2000 primary education was almost universal, with a high completion rate for all socioeconomic strata (column 2 of Panel A), but enrollment in secondary education still varied considerably across the socioeconomic levels (column 3 of Panel A). Even though significant improvements were achieved during the 1990s (Mena and Bellei 1998), with the proportion of students in the lowest quintile attending secondary school rising to 71.9 per cent, there was still a considerable gap in the secondary-school completion rates between rich and poor, ranging from 42.6 to 94.9 per cent.

The gap between the income quintiles grows larger for tertiary education. The total post-secondary enrollment rate is 29.5 per cent, but it reaches 74.8 per cent in the top quintile while it is 5.7 per cent in the bottom quintile (column 5 of Panel A). These differential enrollment rates are important if we consider that the income returns to schooling increase substantially as we advance across educational levels: they are 6 per cent per year for primary education, about 10 per cent per year for secondary education, and more than 20 per cent per year for post-secondary study (Contreras and Larranaga 1999; Beyer 2000). ${ }^{6}$

Until the 1970s the Chilean education system consisted of a public sector with free primary and secondary schooling, serving the large majority of the population, and a private sector serving the wealthiest 10 per cent or so of families. The system was reformed during the $1980 \mathrm{~s}$, as part of the 'structural adjustment program' (Graham 1998, Ch. 2). The reform included the 
Table 8.3 Schooling completion rates of selected age cohorts by income quintile, Chile, $2000^{1}$

Panel A Percentage of the 15-19 age cohort with primary education, of the 20-24 age cohort with secondary schooling, and of the 25-29 age cohort with tertiary education

\begin{tabular}{|c|c|c|c|c|c|c|}
\hline \multirow[t]{2}{*}{ Income quintile } & \multicolumn{2}{|c|}{ 15-19 Cohort } & \multicolumn{2}{|c|}{ 20-24 Cohort } & \multicolumn{2}{|c|}{ 25 29 Cohort } \\
\hline & $\begin{array}{c}1 \\
\text { Some primary }\end{array}$ & $\frac{2}{\text { Completed primary }}$ & $\begin{array}{c}3 \\
\text { Some secondary }\end{array}$ & $\begin{array}{c}4 \\
\text { Completed secondary }\end{array}$ & $\begin{array}{c}5 \\
\text { Some tertiary } 2\end{array}$ & $\begin{array}{c}6 \\
\text { Completed tertiary }\end{array}$ \\
\hline $\begin{array}{l}1 \text { (low) } \\
2 \\
3 \\
4 \\
5 \text { (high) }\end{array}$ & $\begin{array}{l}98.9 \\
99.8 \\
99.5 \\
99.6 \\
99.2\end{array}$ & $\begin{array}{l}85.2 \\
91.1 \\
94.8 \\
97.7 \\
97.9\end{array}$ & $\begin{array}{l}71.9 \\
82.1 \\
89.5 \\
93.9 \\
97.7\end{array}$ & $\begin{array}{l}42.6 \\
56.1 \\
71.5 \\
86.6 \\
94.9\end{array}$ & $\begin{array}{r}5.7 \\
11.0 \\
20.3 \\
40.4 \\
74.8\end{array}$ & $\begin{array}{r}3.1 \\
4.5 \\
10.9 \\
22.0 \\
48.2\end{array}$ \\
\hline Total population & 99.3 & 92.1 & 84.2 & 68.8 & 29.5 & 17.1 \\
\hline
\end{tabular}

A Panel B Schooling completion rates for the 25-29 age cohort

\begin{tabular}{|c|c|c|c|c|c|c|}
\hline Income quintile & Some primary & Completed primary & Some secondary & Completed secondary & Some tertiary ${ }^{2}$ & Completed tertiary $^{2}$ \\
\hline $\begin{array}{l}\text { (low) } \\
2 \\
3 \\
4 \\
5 \text { (high) }\end{array}$ & $\begin{array}{l}97.7 \\
98.7 \\
99.1 \\
99.4 \\
99.8\end{array}$ & $\begin{array}{l}71.9 \\
84.3 \\
92.6 \\
97.1 \\
99.1\end{array}$ & $\begin{array}{l}53.8 \\
71.4 \\
84.3 \\
92.8 \\
97.8\end{array}$ & $\begin{array}{l}30.2 \\
49.7 \\
67.3 \\
84.0 \\
94.9\end{array}$ & $\begin{array}{r}5.7 \\
11.0 \\
20.3 \\
40.4 \\
74.8\end{array}$ & $\begin{array}{r}3.1 \\
4.5 \\
10.9 \\
22.0 \\
48.2\end{array}$ \\
\hline Total population & 98.9 & 88.9 & 80.8 & 64.7 & 29.5 & 17.1 \\
\hline
\end{tabular}

Notes:

1. Excludes DK/NA (don't know/not available) comprising less than 1 per cent of the sample.

2. Tertiary includes academic, professional, and vocational higher education.

Sources: Authors' calculations based on CASEN Survey 2000 (Ministry of Planning 2000) 
following components: first, reallocation of public spending from higher education to primary and secondary schooling, coupled with a reduction in the education budget, from 4.9 to 2.6 per cent of GDP. Second, schools were transferred from ministerial to local government (municipal) control. Third, the financing of education was modified to a voucher system (inspired by Milton Friedman) in which a fixed amount was paid to public schools on the basis of daily attendance rates. Private schools could receive this government subsidy in exchange for not charging students tuition fees (Cox and Lemaitre 1999). ${ }^{7}$

These reforms provided strong incentives for additional private agents to enter the educational sector, and the number of subsidy-based private schools (that is, chartered privately, but receiving the state voucher - what we shall term 'semi-privates') grew dramatically. ${ }^{8}$ As public school quality deteriorated due to cuts in public spending in the 1980 s, the semi-private schools became an increasingly attractive option for middle-class families, unable to access the fully-paid private institutions. The emergence of semiprivate schools occurred primarily in urban areas, but not in rural and less populated locales, where the market was not profitable. Thus, between 1981 and 1999 the percentage of students attending public schools dropped from 78 to 54 per cent, while the percentage enrolled in semi-private institutions rose from 15 to 37 per cent, and the proportion in fully-paid private schools remained constant at about 9 per cent (Ministry of Education 1999, p. 118).

Educational coverage expanded in spite of a decline in resources expended on schooling: secondary enrollment grew from 49.7 to 80 per cent between 1970 and 1990, suggesting that the per-pupil subsidy was an efficient mechanism for adjusting demand to supply (Cox and Lemaitre 1999, Table 4-1). However, learning results did not improve during the $1980 \mathrm{~s}$. Semi-private schools have not been attracted to poor and remote areas of the country, where operational costs are higher; hence, public schools have served an increasingly homogeneous poor population. As is evident in column (1) of Table 8.4, whereas 74 per cent of the bottom-quintile children attend public schools, only 18 per cent of the top-quintile children do so; the proportion attending fully-paid private schools ranges from 1 per cent in the bottom quintile to 56 per cent in the top quintile (column 3). The semi-private schools, in comparison, primarily serve the interior segments of the income distribution.

The segmentation based on ability to pay was reinforced in 1993 when semi-private primary and secondary schools were allowed to charge a copayment fee to supplement the state subsidy. As can be seen in Panels $\mathrm{A}$ and $\mathrm{B}$ of Table 8.5 there is a monotonic decline in student performance in each of the school grades as one moves from fully private to semiprivate and to public school. This decline is consistent across subjects 
Table 8.4 Enrollment by school type and income quintile, 1998

\begin{tabular}{lcccc}
\hline Income quintile & \multicolumn{4}{c}{ Type of school } \\
\cline { 2 - 5 } & $\begin{array}{c}(1) \\
\text { Public }\end{array}$ & $\begin{array}{c}(2) \\
\text { Semi-private }\end{array}$ & Private-paid & Total \\
\hline l(low) & 73.7 & 25.4 & 0.9 & 100.0 \\
2 & 62.5 & 35.3 & 2.2 & 100.0 \\
3 & 54.2 & 40.0 & 5.7 & 100.0 \\
4 & 39.6 & 44.6 & 15.8 & 100.0 \\
5 (high) & 18.1 & 26.3 & 55.6 & 100.0 \\
Total & 54.8 & 33.5 & 11.6 & 100.0 \\
\hline
\end{tabular}

Notes:

1. Includes primary and secondary levels. Omitted from the table are 1.1 per cent of students who attend Corporacion de Administracion Delegada (Delegated Administrative Corporation) schools.

2. State-subsidized private school.

Source: CASEN Survey 1998 (Ministry of Planning 2002b)

(mathematics and Spanish) and across time, though between 1988/89 and $1996 / 97$ there was some contraction in the performance gap among the school types. ${ }^{9}$ Nonetheless, the gap remains very large in 1996/97, suggesting that, in Chile, the quality of education remains closely associated with the ability to pay.

There is evidence that the test scores are heavily influenced by the socioeconomic backgrounds of students and that the educational system is structured in a way that effectively reproduces the existing pattern of social and economic inequality in the country. Not only the amount of human capital invested in children (measured by number of years of schooling), but also the quality of human capital (measured by test scores) is significantly influenced by parental characteristics, with the type of school attended serving as a mediating factor between family background and educational attainment (Medlin 1996; Mizala and Romaguera 1998; Bravo et al. 1999). Yet, a claim that parental resources are salient for educational attainment hardly makes Chilean society unique. The critical question concerns how potent the linkage is, and to what extent children from poor households are handicapped in acquiring sufficient human capital to function in a modern, wage-labor economy. This is one issue that will be addressed in the analysis.

Parental assets can be important for living standards in a second way, by permitting direct transfers to children, especially at key points along the life 
Table 8.5 Mathematics and Spanish test scores, by school type and year

Panel A Fourth graders

\begin{tabular}{|c|c|c|c|c|}
\hline \multirow[t]{2}{*}{ Type of school } & \multicolumn{2}{|c|}{1988} & \multicolumn{2}{|c|}{1996} \\
\hline & $\begin{array}{c}\text { (1) } \\
\text { Spanish }\end{array}$ & $\begin{array}{l}\text { (2) } \\
\text { Math }\end{array}$ & $\begin{array}{c}\text { (3) } \\
\text { Spanish }\end{array}$ & $\begin{array}{l}\text { (4) } \\
\text { Math }\end{array}$ \\
\hline Public & 50 & 48 & 68 & 68 \\
\hline Semi-private* & 58 & 55 & 74 & 73 \\
\hline Fully-paid private & 79 & 73 & 86 & 86 \\
\hline Total & 54 & 52 & 72 & 71 \\
\hline
\end{tabular}

Panel B Eighth graders

\begin{tabular}{|c|c|c|c|c|}
\hline \multirow[t]{2}{*}{ Type of school } & \multicolumn{2}{|c|}{1989} & \multicolumn{2}{|c|}{1997} \\
\hline & $\begin{array}{c}\text { (1) } \\
\text { Spanish }\end{array}$ & $\begin{array}{c}\text { (2) } \\
\text { Math }\end{array}$ & $\begin{array}{c}\text { (3) } \\
\text { Spanish }\end{array}$ & $\begin{array}{l}\text { (4) } \\
\text { Math }\end{array}$ \\
\hline Public & 53 & 52 & 62 & 59 \\
\hline Semi-private* & 59 & 56 & 68 & 65 \\
\hline Fully-paid private & 77 & 76 & 80 & 81 \\
\hline Total & 57 & 55 & 65 & 63 \\
\hline
\end{tabular}

Note:

* State-subsidized private school.

Source: Generated from SIMCE data (Ministry of Education (1989 and 1997), Sistema de Medicion de la Calidad de la Educacion (System of Measurement of the Quality of Education).

cycle: labor market entry, marriage, and at times of illness or job loss. Parental resources can serve as both a capital stock for investment in the earnings capacity of offspring, and as a consumption reserve, analogous in this role to formal credit agencies and informal insurance arrangements among community members. The advantage of parental resources is that children generally have a first call on these assets, and the welfare of offspring can be assumed to be part of the utility function of parents (Becker 1991, Ch. 6) ${ }^{10}$ Without excessive exaggeration we can think of parents and children as 'conspiring' to advance the well-being of the latter through the effective targeting of parental resources.

Moreover, in Chile, for institutional reasons, the vulnerability of the population to economic dislocation is quite high. The labor market has a large informal sector, " there is limited job security for much of the workforce, and programs of unemployment assistance leave substantial portions of 
the workforce uncovered. ${ }^{12}$ In this circumstance, the presence of parental resources may have a strong buffering effect, compensating for the inadequacies of the limited public assistance sector. Therefore, a second issue, which is examined in the paper concerns the contribution of parental resources to household income and wealth holdings - measures, essentially, of the capacity of a family to achieve economic security and maintain a particular living standard.

\section{PARENTAL BACKGROUND, EDUCATIONAL ATTAINMENT, INCOME AND WEALTH}

With this detail about the educational system, we turn to an analysis of parental effects on educational attainment and on the living standard capacity measures. The data for the study come from a module on parental asset holdings and the economic well-being of adult children that was added to a recent survey of job histories. The year 2001 Social Mobility Survey was a nationally representative, random sample of 3544 Chilean households. Respondents were male household heads aged 24-69, who acted as informants about their own background and work experience, and about their wife's, or partner's, background. Descriptive statistics for the main variables are presented in Appendix Table 8A.1, and a comparison with values from CASEN, a national household survey comparable to the Current Population Survey in the United States, is provided in Appendix Table 8A.2.

Two caveats with regard to the data. First, while the conceptual argument emphasizes the role of parental assistance and intergenerational transfers, our observations are restricted to parental assets; a transfer process is presumed to account for the parental effects on living standards but the details of the transmission are not spelled out in this study. Second, low parental income and resources can affect educational attainment in three ways: through its influence on the quality of the school attended (for example, tuition and fees); through the carrying costs of maintaining a child in school, forgoing his/her labor market income; and through residence in poor neighborhoods, where schools are distant or unavailable. While we have a proxy for school quality (private school attendance), we lack a measure of school accessibility in different communities at the time the respondents were in their student years - which means that this reason for low attendance will be confounded with the parental burden of keeping a child in school, a second determinant of low attendance.

At one level the distinction in the underlying cause of low attendance is unimportant; both explanations tap parental income and resources. But the distinction is relevant if one seeks to ameliorate the problem, in that a 
different solution is suggested in each case. Where low rates of attainment are due to a lack of school facilities, the construction of physical plants is indicated; where the problem stems from the parental burden of supporting a dependent child, the response must be quite different. In actuality, we expect the bias from this confounding to be small, especially for respondents aged 45 and younger, because primary and secondary schooling have been available in Chile in all but the most distant rural locales since the late 1960s (Aylwin et al. 1983, Ch. 4; Gazmuri 2000, Vol. II, Chs 7.8). ${ }^{13}$

\section{Descriptive Statistics}

As a preliminary to the multivariate analysis we describe the zero-order relationships among the main variables. The importance of educational attainment for various aspects of family welfare is summarized in Table 8.6. The first five rows refer to household income and financial assets; rows 6-8 describe the association between some key living standard measures (functional assets) and years of schooling. The contribution of education to financial well-being is evident: husband's earnings, total family income, and its stock of financial and investment assets show a strong dependence on years of schooling, with large increases as one moves from low to high levels of education. Not surprisingly, the living standard measures show a similar dependence on schooling; presumably the income and financial resource terms serve as intervening variables in the production of these educational effects.

If we examine the association between the parental standard of living (SOL) - a subjective measure that reflects parental assets and income - and the well-being of adult children we find a similar effect pattern (Table 8.7). The first eight rows exhibit a strong dependence of the financial and living standard measures on parental SOL, with considerably higher respondent values as one progresses along the SOL categories. It can reasonably be assumed that much of the impact of parental resources (indexed by SOL) comes from its effect on husband's schooling (row 9), which ranges over the SOL categories from 7.2 to 14.2 years, and from the consequent impact of husband's education on the couple's income and assets. The last three rows serve a different purpose; they document the association between parental SOL and its presumed objective components: father's education, father's occupational status, and parental wealth. This association serves to validate our contention that the SOL variable can be viewed as a summary measure of parental attainment and resources.

These results provide preliminary evidence for the importance of educational attainment and for the dependence of this variable and, ultimately, living standards on parental resources. In order to identify the mechanisms 
Table 8.6 Descriptive statistics relating measures of couple's financial well-being and standard of living to husband's educational attainment

\begin{tabular}{|c|c|c|c|c|c|c|c|c|}
\hline \multirow[t]{2}{*}{ Financial well-being/SOL } & \multicolumn{8}{|c|}{ Years of schooling by husband } \\
\hline & $0-4$ & $5-6$ & $7-8$ & $9-11$ & 12 & 1316 & $17+$ & $\mathrm{N}$ \\
\hline \multicolumn{9}{|l|}{ Income and financial assets: } \\
\hline Husband's earnings ${ }^{2}$ & 127 & 146 & 166 & 237 & 280 & 469 & 1149 & 2640 \\
\hline Family income $\mathrm{e}^{3}$ & 161 & 186 & 210 & 283 & 362 & 595 & 1411 & 2951 \\
\hline Family wealth ${ }^{4}$ & 3.6 & 4.1 & 4.2 & 4.6 & 4.7 & 5.2 & 6.2 & 3091 \\
\hline Financial assets 5 & 0.06 & 0.08 & 0.11 & 0.17 & 0.23 & 0.33 & 0.61 & 3053 \\
\hline Property ownership ${ }^{6}$ & 0.12 & 0.13 & 0.11 & 0.15 & 0.20 & 0.26 & 0.41 & 3102 \\
\hline \multicolumn{9}{|l|}{ Functional assets: } \\
\hline Number of autos & 0.24 & 0.37 & 0.39 & 0.41 & 0.59 & 0.78 & 1.19 & 3097 \\
\hline Number of household items ${ }^{7}$ & -0.28 & -0.16 & -0.17 & -0.06 & 0.10 & 0.34 & 0.90 & 3079 \\
\hline Home value 8 & 12.3 & 11.6 & 13.4 & 14.8 & 19.5 & 30.3 & 54.2 & 2073 \\
\hline
\end{tabular}

Notes:

1. Entries are for married and cohabitating couples. All values are for year 2001 .

2. Unemployed husbands omitted from the calculation. Entry $\times 1000=$ monthly earnings in pesos

3. Entry $\times 1000=$ monthly family income in pesos.

4. Subjective 10-category scale.

5. Proportion of respondents owning bonds, stock, life insurance.

6. Proportion of respondents owning land, business, real estate.

7. Sum of Z-scores from count of ownership of seven common household items.

8. Computed for homeowners. Entry $\times 1000000=$ home value in pesos.

Source: Social Mobility Survey, 2001. 
Table 8.7 Descriptive statistics relating husband's earnings, couple's financial status and standard of living, to parental standard of living 1

\begin{tabular}{lccccccc}
\hline & \multicolumn{7}{c}{ Parental standard of living } \\
\cline { 3 - 6 } & 1 & 2 & 3 & 4 & 5 & $\mathrm{~N}$ \\
\hline Measures of couple's SOL: & & & & & & \\
Husband's earnings $^{3}$ & 177 & 269 & 424 & 854 & 1475 & 2627 \\
Family income $^{4}$ & 212 & 328 & 524 & 989 & 1693 & 2937 \\
Family wealth $^{5}$ & 3.9 & 4.5 & 5.2 & 5.8 & 6.2 & 3077 \\
Financial assets $^{6}$ & 0.10 & 0.16 & 0.31 & 0.46 & 0.46 & 3041 \\
Property ownership $^{7}$ & 0.12 & 0.17 & 0.24 & 0.32 & 0.41 & 3089 \\
Number of autos & 0.33 & 0.48 & 0.67 & 1.03 & 1.32 & 3085 \\
Number of household iterns $^{8}$ & -0.18 & -0.01 & 0.23 & 0.55 & 0.67 & 3067 \\
Home value $^{9}$ & 12.7 & 16.8 & 25.1 & 43.7 & 79.9 & 2063 \\
Husband's education $^{10}$ & 7.2 & 9.7 & 11.7 & 13.9 & 14.2 & 3083 \\
& & & & & & \\
Parental SOL components: $_{\text {Father's education }}{ }^{10}$ & & & & & & \\
Father's ISEI $^{11}$ & 3.8 & 6.1 & 8.5 & 11.8 & 13.3 & 2465 \\
Parental wealth $^{12}$ & 25.1 & 29.7 & 35.8 & 46.5 & 55.7 & 2771 \\
& 2.5 & 3.9 & 5.3 & 6.8 & 8.2 & 3080 \\
\hline
\end{tabular}

Notes:

1. Entries are for married and cohabitating couples, year 2001 values.

2. Parental SOL is a five-category subjective assessment of husband's parents, pertaining to year when husband was 14 years old.

3. Entry $\times 1000=$ monthly eamings in pesos.

4. Entry $\times 1000=$ monthly family income in pesos.

5. Subjective assessment, 10-category scale.

6. Proportion of respondents owning bonds, stock, life insurance.

7. Proportion of respondents owning land, business, real estate.

8. Sum of Z-scores from count of ownership of seven common household items.

9. Computed for homeowners. Entry $\times 1000000=$ home value in pesos.

10. Years of schooling by husband's father.

11. Occupational score, husband's father - International Socioeconomic Index of Occupational Status (Ganzeboom et al. 1992).

12. Subjective assessment of husband's parents, in year when husband was 14 years old, 10-category scale.

Source: Social Mobility Survey, 2001.

by which the parental terms influence living standards - especially the respective effects through education and direct assistance - we utilize a multivariate formulation. Indeed, it cannot be assumed that the various living standard components are even determined by the same transmission process; some may be heavily influenced by parental investments in schooling, others 
Table 8.8 Impact of parental characteristics on respondent's years of schooling and type of school attended ${ }^{1}$

Explanatory variables

(1)

(2)

Years of schooling ${ }^{2}$ Attended private school ${ }^{3}$

\begin{tabular}{|c|c|c|}
\hline Constant & $8.8588^{* * *}$ & $-5.0811^{* * *}$ \\
\hline Father's education ${ }^{4}$ & $0.2447 * * *$ & $-0.0963 * * *$ \\
\hline Father's education $(m)^{s}$ & -0.3245 & -0.0357 \\
\hline Father's occupation 6 & $0.0601^{* * *}$ & $0.0203^{* * *}$ \\
\hline Father's occupation $(m)^{5}$ & $2,5072^{* * *}$ & 0.2270 \\
\hline Respondent's age & $-0.0804 * * *$ & $0.0131 *$ \\
\hline Number of siblings & $-0.1554^{* * *}$ & $-0.0554^{*}$ \\
\hline Parental wealth (log) & $0.7495^{* * *}$ & $0.2922 * * *$ \\
\hline $\mathrm{R}^{2} / /-2 \mathrm{LL}$ & .433 & 1749 \\
\hline $\mathrm{N}$ & 3483 & 3439 \\
\hline $05,{ }^{* *} p$ & & \\
\hline
\end{tabular}

Notes:

1. Respondents are males, married and unmarried.

2. Unstandardized coefficients from OLS regression.

3. Logistic regression. Dependent variable coded I if last school attended was private; 0 otherwise. Respondents without any formal education excluded from the analysis.

4. Years of schooling.

5. Variables education $(m)$ and occupation $(m)$ are missing data indicators. See text for details.

6. Occupation coded by ISEI status scores (Ganzeboom et al. 1992).

more tightly linked to direct asset transfers. In the present paper we examine parental effects on the determination of husband's education and on the principal measures of living standard potential - husband's earnings; the couple's income and wealth.

\section{Years of Schooling and Type of Institution Attended}

In the traditional socioeconomic achievement model (for example, Blau and Duncan 1967, Ch. 5), years of schooling by the respondent is formulated as a function of father's education and occupational status, the latter serving as a proxy for parental permanent income. In column (1) of Table 8.8 we follow this characterization, with occupation coded by its International Socioeconomic Index (ISEI) score, ${ }^{14}$ though for a more complete depiction of the parental background effects we have added terms for parental wealth and number of siblings, the latter a measure of demands 
on the parental resources. As suggested earlier, parental wealth may well influence educational attainment net of father's education and earnings, because it can generate an income stream that is independent of employment. In times of economic crisis poor families often increase their reliance on child labor (Moser 1998), encouraging older children to enter the labor market. In this circumstance, parental asset holdings could provide a family with the resources to sustain a child in school.

Three additional variables are included as regressors: a term for husband's age and two missing data indicators, for husband's father's education and occupational status. ${ }^{\text {is }}$ The age variable should correct for the tendency of older husbands to have less education; the missing data indicators ( $m$-terms in the table) were added in order to retain observations that have considerable missing data on a variable, as is the case with the parental variables (Table 8A.1). Specifically, an indicator term was coded 1 for cases where data are absent on the substantive variable, and 0 otherwise. Where significant, an indicator term conveys the average effect on the dependent variable from observations for which data are lacking on the substantive regressor. ${ }^{16}$

The results in column (1) support the contention about the importance of parental background and, in particular, the contribution of parental asset holdings. Father's education and occupational status are highly significant, with strong effects on educational attainment. Each additional year of father's schooling increases respondent's education by 0.24 years. Father's occupational status also has a strong impact. Since status is measured on the ISEI scale, which lacks a concrete metric, we note that a standard deviation increase in father's status score - essentially the difference between occupations such as secretary and primary school teacher, or between unskilled farm laborer and carpenter - translates into a gain of 0.94 years in respondent's schooling. (In comparison, a standard deviation increase in father's education generates a gain of 1.18 years in schooling.) The coefficient for respondent's age, as expected, is negative; older Chileans, on average, have less schooling than their younger peers.

The final two variables, indicators of parental resources, also have substantial effects. Since parental wealth is highly skewed, it is more meaningful to report results in terms of the $\log$ (wealth) metric. ${ }^{17} \mathrm{~A}$ one-standard deviation increase in this variable generates a return of 1.02 years in respondent's schooling, an effect that is net of the parental human capital variables. Equivalently, since change in the log(wealth) metric represents a multiplicative effect in the underlying variable, a one-standard deviation increase in $\log ($ wealth $)-1.36$ points - is tantamount to a multiplicative factor of 3.9 (exp[1.36]). Thus, the difference in parental wealth between $\$ 10000$ and $\$ 39000$ (or between $\$ 100000$ and $\$ 390000$ ) is associated with 1.02 years of additional schooling. ${ }^{18}$ 
In short, the returns to parental wealth are roughly of the same magnitude as the returns to the human capital variables. When measured in terms of a standard deviation change (with parental wealth specified in the log metric), each has a considerable effect on educational attainment. In the United States, in comparison, the impact of parental wealth is weaker (for example, Axinn et al. 1997). Possibly because school attendance is compulsory through age 16 in much of the United States, family resources play less of a role as a deterrent to school dropout. Last, sibship size has a negative impact on years of schooling, a finding that has been noted in other studies (for example, Duncan et al. 1972, Ch. 3; Spilerman 2004). A larger family invariably means that less in the way of parental assistance is available to each child.

But the impact on years of schooling is not the only way that parental background and resources can influence the accumulation of human capital. There is evidence in Chile of an association between type of school attended (public, semi-private, private) and the quality of education. For example, Aninat (2000) reports that the school day is some two hours longer in private institutions than in public or semi-private ones; also, test scores are higher in private schools (Table 8.5). We therefore turn to an examination of the effect of parental resources on the channeling of students into one or the other of the parallel school systems.

In column (2) of Table 8.8 logit coefficients are reported from a regression of the dichotomous variable, 'last school attended was private, versus other type' on the parental background terms. Again, the parental effects are highly significant. Exponentiating the logit coefficients permits a comparison of the different background characteristics in terms of odds ratios. In particular, a one-standard deviation increase in parental education (4.76 years) raises the odds of attending private school by 58 per cent; for father's occupational status, a standard deviation shift translates into an odds change of 30 per cent. In comparison, a standard deviation increase in In(parental wealth) produces a 48 per cent improvement in the odds of attending private school. Also worth noting is the negative effect of sibship size, which again suggests the detrimental consequence of having to divide the parental resources among multiple children.

To summarize, the effects of the parental background terms are considerable. Father's education and occupational status exert a major influence on two central components of respondent's educational attainment: years of study and quality of schooling (the latter indexed by private school attendance). Moreover, net of these effects, parental wealth makes an additional contribution to educational attainment that is roughly equal in size, as measured by a standard deviation change in each parental term. Since much wealth is inherited and remains within families, this source of advan- 
tage in access to education can be difficult to overcome solely from public investments in school facilities.

\section{Respondent's Earnings}

From the perspective of living standards, household income and wealth can be viewed as capacity measures. These resources provide the material basis that underlies a family's consumption level; in addition, a family's wealth stock constitutes a consumption reserve, to be drawn upon in the event of sickness or job loss. In the present section we examine the relation between parental background and respondent's earnings; in the following one, using an extended formulation that includes characteristics of spouse's background, we investigate the determinants of household income and wealth.

The impact of parental background on the log of respondent's earnings in year 2001 is reported in Table 8.9. Respondents without employment activity are omitted from this analysis. A Heckman-type selection model was not used because of the unavailability of suitable first-stage regressors. However, the bias in coefficient estimates due to the lack of a correction factor is not great. While some 13.3 per cent of the sample reported no income from employment, the majority of these respondents indicated that this was because they were retired or had chronic illness; in short, they were not available for work. Only 4.6 per cent of the sample reported reasons for inactivity which suggested that they would accept employment.

Column (1) of Table 8.9 presents the total effects of the parental variables; that is, the effects not mediated by respondent's education. The significance pattern is similar to that reported for respondent's education, presumably because years of schooling is the most potent determinant of earnings in a modern economy, and because the parental effects on educational attainment, reported in Table 8.8, are considerable. Again, each of the parental terms - father's education, occupational status, and parental wealth - shows a strong association with respondent's earnings.

The returns to the different parental variables can be summarized as follows: a one-standard deviation increase in father's schooling (4.79 years) translates into a 22 per cent improvement in respondent's earnings $(\exp [0.0417 \times 4.79]=1.22)$. With regard to father's occupational status, an increase of one standard deviation - equivalently a 41 per cent change from its mean value - augments earnings by 21 per cent. Father's wealth has a more modest effect: a one-standard deviation change in $\ln ($ wealth) - a multiplier of 3.9 in the wealth metric-can be associated with an 18 per cent increase in respondent's earnings. While each of these contributions is net of the other terms in the equation, in reality a father with higher education 
Table 8.9 Effects of parental characteristics on respondent's earnings, $2001^{1}$

\begin{tabular}{|c|c|c|c|}
\hline Explanatory variables & $\begin{array}{l}\text { (1) } \\
\text { Total effects } \\
\text { of parental } \\
\text { terms }\end{array}$ & $\begin{array}{c}(2) \\
\text { Effects net } \\
\text { of education }\end{array}$ & $\begin{array}{c}\text { (3) } \\
\text { Effects net } \\
\text { of education } \\
\text { and occupation }\end{array}$ \\
\hline Constant & $4.2184^{* * *}$ & $3.3205^{* * *}$ & $3.2642 * * *$ \\
\hline Father's education ${ }^{2}$ & $0,0417^{* * *}$ & $0.0143^{* * *}$ & $0.0102^{* *}$ \\
\hline Father's education $(m)^{3}$ & 0.0127 & 0.0424 & 0.0323 \\
\hline Father's occupation ${ }^{4}$ & $0.0146^{* * *}$ & $0.0071^{* * *}$ & $0.0044^{* * *}$ \\
\hline Father's occupation $(m)^{3}$ & $0.4414 * * *$ & $0.1646^{* *}$ & 0.0850 \\
\hline Respondent's age & 0.0019 & $0.0093^{* * *}$ & $0.0059^{* * *}$ \\
\hline Number of siblings & $-0.0122^{*}$ & 0.0048 & 0.0048 \\
\hline Parental wealth (log) & $0.1190^{* * *}$ & $0.0382 * * *$ & $0.0312^{* *}$ \\
\hline Respondent's education ${ }^{2}$ & & $0.1068 * * *$ & $0.0695^{* * *}$ \\
\hline Semi-private school ${ }^{5}$ & & 0.0361 & 0.0334 \\
\hline Private school & & $0.2710^{* * *}$ & $0.2159 * * *$ \\
\hline $\begin{array}{l}\text { Respondent's occupational } \\
\text { status }\end{array}$ & & & $0.0195 * * *$ \\
\hline $\mathrm{R}^{2}$ & 0.264 & 0.440 & 0.498 \\
\hline $\mathrm{N}$ & 2855 & 2855 & 2855 \\
\hline \multicolumn{4}{|c|}{${ }^{*} p<0.05,{ }^{* *} p<0.01,{ }^{* * *} p<0.001$} \\
\hline
\end{tabular}

Notes:

1. Unstandardized coefficients from OLS regressions. Dependent variable is $\ln$ (earnings), with earnings in pesos. Respondents are males, married and unmarried. Respondents without earnings are omitted from the analysis. See text for details on model specification.

2. Educational attainment measured by years of schooling.

3. Variables education $(m)$ and occupation $(m)$ are missing data indicators. See text for details.

4. Occupation coded by ISEI status scores (Ganzeboom et al. 1992).

5. Institutional type of last school attended. Public school is the deleted term.

is likely to also have higher occupational status and greater wealth, producing a cumulatively more potent parental impact on earnings.

To what extent do these parental effects operate through the determination of educational attainment? This question is addressed in column (2), where respondent's education and school type have been added to the equation. As expected, the contribution from the educational terms is considerable. An additional year of study has a multiplier effect of 1.113 (an 11.3 per cent increase in earnings), four years of study - the difference between primary school and high school - translates into an increase of 53 per cent in respondent's earnings. 
Enrollment in private school, in contrast with public school attendance, is worth 31 per cent more in earnings, an effect that is in addition to years of study.

The degree to which the educational variables serve to transmit the parental effects can be ascertained by examining the reduction in the coefficients in equation (2) versus equation (1). The three parental variables remain significant, suggesting that family background and resources influence earnings in ways apart from their impact on educational attainment, but the coefficients are much smaller. The reductions vary from 51 per cent to 68 per cent; thus, the bulk of determination of respondent's earnings by the parental variables comes from their impact on the educational terms. In column (3) respondent's occupational status has been added, revealing a second avenue of parental influence on earnings. The decline in direct parental effects, relative to equation (1), now ranges from 70 to 76 per cent.

\section{Household Income}

The influence of parental background on family income and wealth holdings is formulated differently from the determination of respondent's education and earnings because it must now be assumed that the respondent's family has access to the resources of both sets of parents. Thus, we change the unit of analysis from the individual to the couple, and introduce regressors for the educational attainment and occupational status of the fathers of both members of the couple; we also restrict the analysis to the 89 per cent of the sample that is currently married or cohabitating. However, since only 31 per cent of the wives are employed either full or part time, we omit regressors for wife's human capital - that is, the determinants of her earnings - to simplify the formulation.

The parental wealth variable was collected only for respondent's (that is, husband's) family. The omission of wife's family wealth can be expected to bias the coefficient of the included wealth variable upwards, due to the likely positive correlation in net worth between the two sets of parents. ${ }^{19}$ Similarly, data are available only for number of siblings of husband, which may introduce an analogous distortion. Other changes to the prior formulation include the introduction of terms for number of employed family members and a dummy term for cohabitation versus marriage.

The results of this analysis are reported in Table 8.10. In column (1) the total effects of the parental background terms on $\ln$ (family income) are presented. These show significant contributions for father's education and occupation (from each set of parents) and for parental wealth. Net of the other variables, four years of added schooling by husband's father is worth 12 per cent in respondent's family income (a multiplier of 1.12), while a one-standard deviation increase in father's occupational status is 
Table 8.10 Effects of parental characteristics on family income, $2001^{1}$

Explanatory variables

(1)

(2)

(3)

Total effects of
parental terms

Effects net of parental terms education education and occupation

\begin{tabular}{|c|c|c|c|}
\hline Constant & $3.807 * * *$ & $3.083^{* * *}$ & $3.058 * * *$ \\
\hline \multicolumn{4}{|l|}{ Husband's father: } \\
\hline Education ${ }^{2}$ & $0.0280^{* * *}$ & $0.0083^{*}$ & 0.0056 \\
\hline Education $(m)^{3}$ & -0.0695 & -0.0220 & -0.0326 \\
\hline Occupation 4 & $0.0108^{* * *}$ & $0.0056^{* * *}$ & $0.0036 * *$ \\
\hline Occupation $(m)^{3}$ & $0.3396^{* * *}$ & $0.1321^{*}$ & 0.0738 \\
\hline \multicolumn{4}{|l|}{ Wife's father: } \\
\hline Education ${ }^{2}$ & $0.0290 * * *$ & $0.0140^{* * *}$ & $0.0101^{* *}$ \\
\hline Education $(m)^{3}$ & 0.0345 & 0.0011 & -0.0036 \\
\hline Occupation $^{4}$ & $0.0121 * * *$ & $0.0078^{* * *}$ & $0.0060^{* * *}$ \\
\hline Occupation $(m)^{3}$ & $0.3840^{* * *}$ & $0.2575^{* * *}$ & $0.2103^{* * *}$ \\
\hline Husband's age & 0.0023 & $0.0090^{* * *}$ & $0.0059^{* * *}$ \\
\hline Number employed 5 & $0.2646^{* * *}$ & $0.2638 * * *$ & $0.2566^{* * *}$ \\
\hline Cohabitation & $-0.2321^{* * *}$ & $-0.1508^{* * *}$ & $-0.1322^{* * *}$ \\
\hline Number of siblings ${ }^{6}$ & $-0.0108^{*}$ & 0.0019 & 0.0020 \\
\hline Parental wealth $(\log )^{7}$ & $0.0840^{* * *}$ & $0.0262^{*}$ & $0.0220^{*}$ \\
\hline \multirow{4}{*}{\multicolumn{2}{|c|}{$\begin{array}{l}\text { Husband's education }{ }^{2} \\
\text { Semi-private school }^{8} \\
\text { Private school }^{8} \\
\text { Husband's occupation }\end{array}$}} & $0.0973^{* * *}$ & $0.0683^{* * *}$ \\
\hline & & -0.0125 & -0.0146 \\
\hline & & $0.2954^{* * *}$ & $0.2539^{* * *}$ \\
\hline & & & $0.0172^{* * *}$ \\
\hline $\mathrm{R}^{2}$ & 0.370 & 0.496 & 0.534 \\
\hline $\mathrm{N}$ & 2807 & 2807 & 2807 \\
\hline \multicolumn{4}{|c|}{${ }^{*} p<0.05,{ }^{* *} p<0.01,{ }^{* * *} p<0.001$} \\
\hline
\end{tabular}

Notes:

1. Unstandardized coefficients from OLS regressions. Dependent variable is $\ln$ (family income), with income in pesos. Respondents are males, married and cohabitating. See text for details on model specification.

2. Educational attainment measured by years of schooling.

3. Variables education $(m)$ and occupation $(m)$ are missing data indicators.

4. Occupation coded by ISEI status scores (Ganzeboom et al. 1992).

5. Number of family members employed.

6. Number of siblings of husband.

7. Estimate of husband's parents" wealth holdings See text for details.

8. Institutional type of last school attended by husband. Public school is the omitted category. 
associated with 15 per cent higher income. (The findings for wife's father's education and occupation are similar.) The parental wealth effect can be described as follows: if husband's father's wealth were doubled, husband's family income would be higher by 6.0 per cent. As to the controls, each additional employed family member, on average, augments family income by 30 per cent, while number of siblings and cohabitation have negative effects, the latter associated with 21 per cent less income in comparison with married respondents.

In the column (2) model, terms have been introduced for husband's educational attainment. First note that both years of study and private school attendance have strong effects on the dependent variable. Four years of added schooling serve to increase household income by 48 per cent, while private school attendance is worth 34 per cent in additional family income. The education terms also serve to transmit the effects of the parental background variables. In this regard, observe that the coefficients of husband's father's schooling and occupation are reduced by 70 per cent and 48 per cent, respectively, (with similar reductions for wife's father's terms), and the parental wealth variable is lessened by some 70 per cent; in short, the major part of the parental influence on income comes through its impact on educational attainment.

A further delineation of the parental effects is conveyed by equation (3), in which a term has been added for husband's occupational status. Not surprisingly, the impact of this term is considerable: a one-standard deviation increase in status is associated with 28 per cent greater family income (a multiplier of 1.28). The coefficient of the schooling variable is now smaller by 30 per cent, since much of the educational effect on earnings would come through the occupation term. What is surprising is that the reduction is modest, which suggests that there is considerable variation in education and income within the occupational categories. A final remark about the controls: number of employed family members and husband's age have positive effects on family income - as one would expect -- while cohabitation has a negative impact. Since the last is net of husband's age, education, and occupational status, as well as of the parental background measures, it is not clear what is being tapped by this variable.

\section{Wealth Holdings}

Parental wealth can play a role in the intergenerational transmission of advantage in two ways. First, by its influence on educational attainment parental wealth facilitates the buildup of human capital in the next generation, thereby contributing to the earnings capacity and household income of offspring; indeed, we find evidence for such an effect in Tables 8.8-10. 
There is also a small, but significant, parental wealth effect on earnings and household income net of the controls for education and occupation (columns (3) of Tables 8.9 and 8.10), suggesting the presence of complex paths in the transmission of advantage, possibly the use of social capital by wealthy and well-connected parents to help children locate a quality job within the range of positions covered by an occupational title.

A second way that parental wealth contributes to the replication of inequality is through direct transfers of material and financial assets. This is the theme of the present section, in which respondent's household wealth is examined in terms of the parental background variables and respondent's education and occupation. Like parental wealth, information on respondent's wealth level was collected in terms of a 10-category ordinal scale, with the category midpoints subsequently assigned interval values based on the estimates of Chilean informants (see note 17). Some caveats in terms of model formulation: since household wealth represents an accumulation over the life course, the use of current values of the explanatory variables as regressors is problematic. Thus, in the case of husband's occupation - a proxy for earnings flows to the household - we replace current occupation by occupation held six years earlier. ${ }^{20}$ In the case of number of employed family members, we have available only the current value, which is used in the analysis.

The regression results for respondent's wealth holdings are reported in Table 8.11. In column (1) the total effects of the parental terms are presented, modified only by the control variables - characteristics of husband and his family that are relevant to the analysis, but which are presumed not to be vehicles in the transmission of parental advantage. The findings are quite clear. There are modest effects from parental education and occupation (the former is significant for husband's father, the latter for wife's father). Also, the controls have effects that are in line with our expectations: household wealth increases with husband's age (a proxy for accumulation time) and with number of employed family members, and it is lower in instances of cohabitation - on average, this marital status is associated with 27 per cent less asset value.

If parental education and occupation have modest effects, this is decidedly not the case with the parental wealth term. Whereas four years of added study by husband's father translates into a 6.7 per cent wealth gain, and a standard deviation improvement in wife's father's status is worth 12.1 per cent, a doubling of parental wealth is associated with a 26 per cent increase in respondent's asset value. A comparison with the parental effects in the income regression (equation (1) of Table 8.10) is instructive: the same manipulations of the parental variables generated income gains of 12 per cent from father's education, 15 per cent from occupational status, but only 6 per cent from parental wealth; the influence pattern in the earnings regression is similar. In short, the effects of the parental human capital terms 
Table 8.11 Impact of parental characteristics on family wealth holdings, $2001^{1}$

\begin{tabular}{|c|c|c|c|}
\hline Explanatory variables & $\begin{array}{l}\text { (1) } \\
\text { Total effects of } \\
\text { parental terms }\end{array}$ & $\begin{array}{l}\text { (2) } \\
\text { Effects net of } \\
\text { education }\end{array}$ & $\begin{array}{l}\text { (3) } \\
\text { Effects net of } \\
\text { education and } \\
\text { occupation }\end{array}$ \\
\hline
\end{tabular}

Constant

$1.5640^{* *}$

$1.0041 * * *$

$0.9941^{* * *}$

Husband's father:

\begin{tabular}{|c|c|c|c|}
\hline Education ${ }^{2}$ & $0.0162^{* *}$ & 0.0034 & 0.0024 \\
\hline Education $(m)^{3}$ & -0.0582 & -0.0244 & -0.0299 \\
\hline Occupation $^{4}$ & 0.0001 & -0.0025 & $-0.0037^{*}$ \\
\hline Occupation $(m)^{3}$ & 0.0738 & -0.0640 & -0.0985 \\
\hline \multicolumn{4}{|l|}{ Nife's father: } \\
\hline Education $^{2}$ & 0.0106 & 0.0011 & -0.0003 \\
\hline Education $(m)^{3}$ & -0.0222 & -0.0395 & -0.0345 \\
\hline Occupation ${ }^{4}$ & $0.0084^{* * *}$ & $0.0055^{* *}$ & $0.0044^{* *}$ \\
\hline Occupation $(m)^{3}$ & $0.2517 * * *$ & $0.1654^{*}$ & 0.1356 \\
\hline Husband's age & $0.0066^{* * *}$ & $0.0116^{* * *}$ & $0.0090^{* * *}$ \\
\hline Vumber employed ${ }^{\mathrm{S}}$ & $0.0901 * * *$ & $0.0900^{* * *}$ & $0.0885^{* * *}$ \\
\hline Cohabitation & $-0.3104^{* * *}$ & $-0.2509^{* * *}$ & $-0.2461^{* * *}$ \\
\hline Vumber of siblings ${ }^{6}$ & -0.0035 & 0.0057 & 0.0059 \\
\hline arental wealth $(\log )^{7}$ & $0.3373^{* * *}$ & $0.2958 * * *$ & $0.2940^{* * *}$ \\
\hline \multicolumn{2}{|l|}{ Husband's education ${ }^{2}$} & $0.0707^{* * *}$ & $0.0537^{* * *}$ \\
\hline \multicolumn{2}{|l|}{ emi-private school ${ }^{8}$} & -0.0005 & -0.0066 \\
\hline \multicolumn{2}{|l|}{ rivate school ${ }^{8}$} & 0.0280 & 0.0173 \\
\hline \multicolumn{3}{|c|}{ Husband's occupation $(1995)^{9}$} & $0.0109 * * *$ \\
\hline \multicolumn{3}{|c|}{ Husband's occupation $(m)^{3}$} & $0.3125^{* * *}$ \\
\hline
\end{tabular}

\begin{tabular}{lrrr}
\hline $\mathrm{R}^{2}$ & 0.273 & 0.313 & 0.324 \\
$\mathrm{~N}$ & 2957 & 2957 & 2957 \\
${ }^{*} p<0.05,{ }^{* *} p<0.01,{ }^{* * *} p<0.001$ & & \\
\hline
\end{tabular}

\section{Notes:}

1. Unstandardized coefficients from OLS regressions. Dependent variable is In(family wealth), with wealth in pesos. Respondents are males, married and cohabitating. See text for details on model specification.

2. Educational attainment measured by years of schooling.

3. Variables education $(m)$ and occupation $(m)$ are missing data indicators.

4. Occupation coded by ISEI status scores (Ganzeboom et al. 1992).

5. Number of family members employed.

6. Number of siblings of husband.

7. Estimate of husband's parents' wealth holdings. See text for details.

8. Institutional type of last school attended by husband. Public school is the deleted term.

9. Husband's occupational status in 1995 (ISEI code). See text for details. 
and parental asset holdings are reversed, with parental education and occupation having the larger impact on earnings and household income, and parental wealth having the dominant effect in the determination of the value of respondent's asset holdings.

To what extent do the parental background terms operate through their impact on the offspring's education and occupation? This question is addressed in columns (2) and (3). Note, first, from equation (2), that years of schooling by the respondent has a strong effect on asset value - four years of additional study can be associated with a 32.7 per cent increase in wealth holdings. But is this effect due to the transmission of parental advantage? Since husband's father's education is now insignificant and wife's father's occupation, while significant, is lower by 34.3 per cent, it is evident that respondent's education serves to transmit much of the influence of parental human capital.

In contrast, the coefficient for parental wealth remains massive-lessened by only 12.3 per cent from the introduction of the schooling variables - a strong indication that the parental wealth effect largely operates outside the educational system. Moreover, the addition of respondent's occupation (column (3)) produces no further reduction in the parental wealth term. As a consequence, an explanation of the association between the value of asset holdings in the two generations that emphasizes the parental wealth effect on respondent's education and occupational attainment does not fare well.

This last assessment need not have been the case. A strong influence of parental wealth on respondent's asset holdings could have come about through a parental wealth effect on education and earnings (indexed here by occupational status). Such a finding would suggest that respondent's asset holdings are accumulated through savings from labor market income, made possible by the parental wealth effect on human capital. But this is not what we discern. Parental wealth does impact the human capital of offspring (Table 8.8); however, this influence path does not account for the value of respondent's asset holdings. Rather, the evidence suggests that, in Chile, at the current time, wealth holdings are best explained by a process of direct transfers across generations.

\section{CONCLUSIONS}

We return to the themes that were raised in the introduction: how important are parental background and parental resources for the life chances and living standards of adult children? What is the particular contribution of parental wealth? What are the implications of this analysis for the persistence of inequality and for policy formulation on these issues? 
As to parental background, the effects on the measures of living standard capacity are considerable. The parental terms, along with respondent's age and number of siblings, account for some 44 per cent of the variation in years of schooling ( $\mathbf{R}^{2}$ in column (1) of Table 8.8). The parental terms also explain 26 per cent of the earnings variation, 37 per cent of the variation in household income, and 27 per cent in household wealth (column (1) of Tables 8.9-11). These are large effects and suggest a strong transmission of advantage across generations.

From the point of view of individual opportunity, the good news is that respondent's education and occupational status account for an additional 23 and 17 per cent of the variation in earnings and household income, respectively (column (3) of Tables 8.9-10). Thus, it is not the case that education and occupational attainment are purely vehicles in the transmission of parental advantage, though they clearly serve this function. Moreover, it is likely that more refined measures of educational attainment and occupational affiliation than we have available would raise the contributions of these terms, as measured by added $\mathrm{R}^{2}$. The key point is that the school system in Chile appears to operate in a way that provides real opportunity for children who do not come from advantaged backgrounds.

The story with respect to household wealth is less sanguine. The same formulation that showed respondent's education and occupation as uniquely accounting for 17 per cent of household income, finds that respondent's human capital explains only 5 per cent of the variance in household wealth, net of the parental terms (column (3) of Table 8.11). Admittedly, the wealth measures are crude; both parent's and respondent's asset values are based on subjective assessments. Moreover, the model specification is hardly optimal for a process in which wealth holdings are built up, at least in part, from accumulations over the life course. Nonetheless, the results for household wealth, both in regard to the small added $R^{2}$ from respondent's education and occupation, and with respect to the failure of these human capital terms to depress the parental wealth coefficient, are consistent, and therefore worrisome.

Also, this finding makes sense in light of the great difficulty that many households face in accumulating savings from earnings, especially in a country in which median income is low. Thus, the expenditures that are necessary for maintaining a minimally acceptable living standard often see little left over for savings. As a consequence, differences in parental wealth holdings become a major determinant of the variation in household wealth in the current generation, an initial condition that is difficult to alter solely by means of investments in schooling and human capital. Indeed, commenting on wealth disparities between black and white Americans, Blau and Graham (1990) make a similar point, noting that even if the racial gap 
in household income in the United States were eliminated, it would take several generations before the existing wealth disparity between the races was significantly eroded.

Yet, while we find strong evidence of a replication of household wealth across generations, only modestly offset by opportunities for education and earnings, there remains a question of the importance of household wealth for living standards and family well-being. It is a quite different matter if variations in wealth holdings correlate with ownership of a BMW versus a Volkswagen, than if the wealth holdings predict car ownership versus no car, or, of greater pertinence, high-school completion versus dropping out of school. The critical issue concerns the extent to which families can finance an acceptable living standard and provide for their children's future solely from labor market earnings. A related issue concerns the availability of safety-net programs in a country that can offset the need for accumulating private savings as a consumption reserve in the event of illness or job loss.

We cannot formally assess the role of household wealth as a determinant of living standards because the current study did not examine the ownership of functional assets (for example, home, car, household durables) or the manner of financing other lifestyle items (for example, vacation travel). But we can speculate on the likely importance of household wealth for consumption expenditures. In particular, it would seem that where a large sum is required, such as for the purchase of a home or starting a small business, this is likely to come from accumulated savings. In Israel, for example, it has been found that parental wealth is a critical resource for these sorts of expenditures, reducing, especially, the waiting time to home ownership by a young couple (Spilerman 2004).

Chile has made great progress since the mid-1980s, improving educational attainment, raising median income, and reducing poverty. This has not been accompanied, however, by a lessening of income inequality, nor, presumably, of wealth inequality, though measures of the latter are lacking. Yet, if income inequality has proven resilient to modification, this is likely to be even more so for wealth inequality, since the latter is less a contemporaneous variable than a historical record of intergenerational transfer receipts and long-term accumulations.

However, precisely because intergenerational transfers play a huge role in the replication of advantage and raise fundamental questions of equity, it is important for a country to avoid high and persistent inequality in initial conditions and maintain realistic possibilities for upward mobility in living standards (Cowan and De Gregorio 2000). Toward this end, the Chilean government might well contemplate strategies that create asset value for poor people, beyond investments in education and labor market skills, such 
as fostering pension savings among informal workers, facilitating access to credit markets, and providing good title to homes. Although the noneconomic externalities from very high inequality have not been addressed in this chapter, their political and social consequences are quite evident in many countries of Latin America.

A final comment should be made about the mechanics of intergenerational financial linkages. This chapter has examined the relevance of parental assets for living standards and the reproduction of inequality. However, we have yet to explore the characteristics of the transfer regimes in Chile. What is the relative importance of inter vivos assistance versus bequests, in the metric of amounts transferred? Which life course events (for example, marriage, birth, illness, job loss) and what sorts of children's characteristics (for example, gender, marital status, financial need, emotional closeness to parents) determine the timing and pattern of parental allocations? How does the availability of public assistance programs interact with family decisions in regard to inter vivos transfers? These are some open issues that are relevant to obtaining a refined understanding of the structure of opportunity and family welfare in the country, and the role played by household wealth in these matters.

\section{NOTES}

* This research was supported by Ford Foundation grant no. 1010-2002 to the Center for the Study of Wealth and Inequality, Columbia University. We would like to thank Guillermo Wormald for making available sections of the Social Mobility Survey for which he was responsible. We would also like to thank Hanna Cho and Hsien-Hen Lu for their comments on an earlier draft.

1. As a practical consideration, IDAs would have to be structured so that the asset holdings do not alter a family's eligibility to receive means-tested welfare payments.

2. Poverty increased significantly in Latin America during the economic crisis of the 1980s, then declined moderately during the 1990 s as a result of economic stabilization policies. In 1999 the poverty rate was 35.3 per cent (ECLAC 2001, Table 1.2).

3. Inequality and poverty are closely related in Latin America. Most countries register 'excess poverty' (rates that are above what would be expected given the GDP per capita) as a result of high levels of income inequality (Attanasio and Szekely 1999).

4. Some important, recent studies of material assets are reported in Attanasio and Szekely (2001), in which attention is given to the role of home ownership, capital, land, and household durables in investigations of economic well-being and living standards in several Latin American countries. For a discussion of the role of material assets in strategies for overcoming poverty, see Stallings et al. (2000).

5. Neighborhoods of such homes go by various names in the different Latin American countries: tugorio in Colombia, poblacion callampa in Chile, favela and villa miseria in Brazil, and cantegril in Uruguay.

6. In Europe a person with a college education receives about 1.8 times the earnings of a person with a primary education; in Chile the figure is 5.5 (Beyer 2000).

7. Despite the absence of tuition charges, the attractiveness of this arrangement to the private sector came from the presence of considerable inefficiencies in the public school 
system which permitted the new schools to be profitable with targeted student populations. Moreover, unlike the public schools they could select students, avoiding the most troublesome and time-consuming children.

8. While a few subsidy-based private schools existed before the 1980 reform, they received roughly half the per-student support given to the public schools.

9. The reduction in this gap was mainiy a result of aggressive educational policies undertaken by the democratic governments since 1990 . These policies include higher public spending, an increase in hours of instruction, and an enhanced educational curriculum (Cox and Lemaitre 1999). However, shorter school days in the subsidized system, in comparison with fully private schools, remains a problem (Aninat 2000).

10. A common way by which Chilean parents use their resources to assist children is by permitting coresidence in the years following marriage. In the data of the current survey, 46.6 per cent of respondents report that they lived with parents for some period during their first three years of marriage or cohabitation.

11. Estimates of the proportion of the labor force engaged in informal employment are in the region of 35 per cent (International Labor Organization 1998).

12. In 1998 an unemployed worker, on average, received $\$ 300$ for a full unemployment spell, which had a median duration of approximately four months (World Bank $2001, \mathrm{Ch} .4$ ). In 2001 the Chilean Congress approved a new system of unemployment insurance, based on unemployment savings accounts, which is expected to widen the population of covered workers.

13. Some evidence that the problem of low educational attainment is principally one of dropping out of school can be seen in Panel B of Table 8.3. For the lowest-income group the 'some primary' rate is 97.7 per cent; however, the completion rate for primary study is 71.9 per cent. Thus, although virtually all in this cohort had access to primary schooling, some 26 per cent departed before completion of study. Nor is this a recent development. Calculations from CASEN 2000 for the 35-39 age cohort show a similar pattern: a primary school enrollment rate of 97.4 per cent for the lowest quintile and a completion rate of 61.6 per cent. The enrollment rate in secondary school is lower and we do not know the extent to which this reflects access problems versus parental financial constraints, but. again, there is evidence of a significant dropout subsequent to beginning study.

14. A measure of occupational status developed by Ganzeboom et al. (1992).

15. The missing data indicator for father's occupational status includes armed forces service, a heterogeneous category with respect to military rank.

16. This treatment of missing data does not correct for bias any more than would the insertion of variable means or listwise deletion of observations unless the data are missing completely at random (MCAR). But it does permit the retention of observations with missing data and the indicator term provides information on the likely direction of the bias.

17. Parental wealth was measured by a subjective rating based on the following question: 'Compare your household when you were age 14 with all Chilean households at that time. On a scale of $I$ to 10 , where $I$ is the poorest and 10 the wealthiest, where would you place your household?'. Two analyses were carried out with different codings of this variable:

(a) We treated the ordinal scale values as measures of $\ln$ (parental wealth), thereby assuming that respondents replied in terms of percentage changes. This reflects the view that an additional $\$ 50000$ has a quite different meaning to a household worth $\$ 10000$ than to one worth $\$ 500000$.

(b) We averaged ratings from five Chileans as to the peso cutting points they would assign to the 10 categories, then used the midpoints as category values. (This is the formulation reported in the text tables.) If the latter estimates are logged, they yield the range 0 to 7.20 . with a mean of 2.95 and a standard deviation of 1.36 . In comparison, the 10-category scale, recoded as 0 to 9 , has a mean of 3.10 and a standard deviation of 1.76. In short, the two formulations are quite similar and the regression estimates from using the 10-point scale, considered as $\log$ values, are very close to the ones reported in the text. 
18. An alternate calculation, based on change in unlogged parental wealth, suggests that a one-standard deviation increase translates into 1.7 additional years of schooling, with the variables evaluated at their means. As noted, because of the skewed nature of the wealth distribution the log(wealth) metric provides the more conservative estimate, and it is the one reported in the text.

19. This omission can also be expected to bias upward the coefficients of wife's father's education and occupation. However, the size of this bias can be estimated by comparing the relative effect on these coefficients, and on the corresponding terms for husband's father, from the introduction of the wealth variable for husband's parents. Calculated in this way, the bias is about 15 per cent.

20. An alternative choice of occupation, availabie in the data set, is 'first occupation after completion of schooling'. Since the rate of job changing is highest in the early years of the work career, first occupation is expected to be a poor indicator of long-term occupational affiliation, and we used, instead, the reported measure. In point of fact, the results are not sensitive to whether first occupation, occupation six years ago, or current oceupation is used as a regressor.

\section{REFERENCES}

Ackerman, B., and A. Alstott (1999), The Stakeholder Society, New Haven, CT: Yale University Press.

Altimir, O. (1998), 'Inequality, employment and welfare in Latin America: challenges and opportunities', in V. Tokman and G. O'Donnell (eds), Poverty and Inequality in Latin America, Notre Dame, IN: University of Notre Dame Press, pp. 3-35.

Aninat, E. (2000), 'Economic growth, social equity, and globalisation: the Chilean case', in A. Solimano, E. Aninat and N. Birdsall (eds), Distributive Justice and Economic Development. The Case of Chile and Developing Countries, Ann Arbor, MI: University of Michigan Press, pp. 119-26.

Attansio, O., and M. Szekely (1999), 'An asset-based approach to the analysis of poverty in Latin America', IADB working paper R-376, Washington, DC: InterAmerican Development Bank.

Attansio, O., and M. Szekely (2001), Portrait of the Poor. An Assets-Based Approach, Washington, DC: Inter-American Development Bank.

Axinn, W., G. Duncan and A. Thornton (1997), 'The effects of parents' income, wealth and attitudes on children's completed schooling and self-esteem', in G. Duncan and J. Brooks-Gunn (eds), Consequences of Growing Up Poor, New York: Russell Sage, pp. 518-40.

Aylwin, M., C. Bascunan, S. Correa, C. Gazmuri, S. Serrano and M. Tagle (1983), Chile en el Siglo $X X$ (Chile in the Twentieth Century), Santiago: Emission.

Becker, G. (1991), A Treatise on the Family, Cambridge, MA: Harvard University Press.

Beyer, H. (2000), 'Educacion y desigualdad de ingreso: una nueva mirada' (Education and income inequality: a new approach), Estudios Publicos, 77, Santiago: Centro de Estudios Publicos.

Birdsall, N., C. Graham and R. Sabot (1998), Beyond Tradeoffs. Market Reforms and Equitable Growth in Latin America, Washington, DC: IADB/Brookings Institution Press.

Birdsall, N., and J.L. Londono (1997), 'Asset inequality does matter: lessons from Latin America', working paper, Washington, DC: Inter-American Development Bank. 
Blau, F, and J. Graham (1990), 'Black-white differences in wealth and asset composition', Quarterly Journal of Economics, 105, 321-40.

Blau, P., and O.D. Duncan (1967), The American Occupational Structure, New York: John Wiley \& Sons.

Bravo, D., and D. Contreras (1999), La Distribution del Ingreso en Chile 1990-1996: Analisis del Impacto del Mercado del Trabajo y las Politicas Sociales (Income Distribution in Chile 1990-1996: Analysis of the Impact of the Labor Market and Social Policies), Santiago: Department of Economics, Universidad de Chile.

Bravo, D., D. Contreras and C. Sanhuenza (1999), Rendimiento Educacional, Desigualdad y Brecha de Desempeno PrivadolPublico: Chile 1982-1997 (Educational Performance, Inequality and the Private/Public Gap: Chile 1982-1997), Santiago: Department of Economics, Universidad de Chile.

Central Bank of Chile (2002), Indicadores Economicos, accessed at: www.bcentral.cl/indicadores/indicadores.htm.

Cohen, G.A. (1993), "Equality of what? On welfare, goods and capabilities', in $\mathbf{M}$. Nussbaum and A. Sen (eds), The Quality of Life, Oxford: Clarendon Press, pp. $9-29$.

Contreras, D, and O. Larranaga (1999), 'Los Activos y Recursos de la Poblacion Pobre en America Latina: El Caso de Chile" (Assets and resources of the poor in Latin America: the Chilean case), IADB working paper R-358, Washington, DC: Inter-American Development Bank.

Cowan, K., and J. de Gregorio (2000), 'Distribution and poverty in Chile today: have we gained or lost ground?', in A. Solimano, E. Aninat and N. Birdsall (eds), Distributive Justice and Economic Development. The Case of Chile and Developing Countries, Ann Arbor, MI: University of Michigan Press, pp. 127-54.

Cox, C., and M.J. Lemaitre (1999), "Market and state principles of reform in Chilean education: policies and results', in G. Perry and D. Leipzinger (eds), Chile: Recent Policy Lessons and Emerging Challenges, Washington, DC: World Bank, pp. 14988.

De Soto, H. (2000), The Mystery of Capital, New York: Basic Books.

Duncan, O.D., D. Featherman and B. Duncan (1972), Socioeconomic Background and Achievement, New York: Seminar Press.

ECLAC (2001), Panorama Social de America Latina 2000-2001 (Social Panorama of Latin America), Santiago: ECLAC.

Edin, K. (2001), 'More than money: the role of assets in the survival strategies and material well-being of the poor', in T. Shapiro and $\mathrm{E}$. Wolff (eds), Assets for the Poor, New York: Russell Sage, pp. 206-31.

Friedman, M. (1962), Capitalism and Freedom, Chicago: University of Chicago Press.

Gallart, M.A. (1998), 'Restructuring, education and training', in V. Tokman and G. O'Donnell (eds), Poverty and Inequality in Latin America, Notre Dame, IN: University of Notre Dame Press, pp. 91-118.

Ganzeboom, H., P. de Graaf and D. Treiman (1992), 'A standard international socio-economic index of occupational status', Social Science Research, 21, 1-56.

Gazmuri, C. (2000), Eduardo Frei Montalva y su Epoca (Eduardo Frei Montalva and his Epoch), Vol. II, Santiago: Aguilar.

Graham, C. (1998), Private Markets for Public Goods, Washington, DC: Brookings Institution Press.

Holtz-Eakin, D., and T. Smeeding (1994), 'Income, wealth and intergenerational economic relations of the aged', in L.G. Martin and S.H. Prestion (eds), Demography of Aging, Washington, DC: National Academy Press, pp. 102-45. 
Inhaber, H., and S. Carroll (1992), How Rich is Too Rich?, New York: Praeger.

International Labour Organization (1998), Chile, Crecimiento, Empleo y el Desafio de la Justicia Social (Chile: Growth, Employment and the Challenge of Social Justice), Santiago: OIT.

Katzman, R., L. Beccaria, F. Filgueira, L. Golbert and G. Kessler (1999), 'Vulnerabilidad, Activos y Exclusion Social en Argentina y Uruguay (Vulnerability, Assets and Social Exclusion in Argentina and Uruguay), working document 107, Santiago: ILO/Ford Foundation.

Kotlikoff, L.J, and L.H. Summers (1981), "The role of intergenerational transfers in aggregate capital accumulation', Journal of Political Economy, 89, 706-32.

Kotlikoff, L.J., and L.H. Summers (1988), "The contribution of intergenerational transfers to total wealth: a reply', in D. Kessler and A. Mason (eds), Modelling the Accumulation and Distribution of Wealth, Oxford: Clarendon Press, pp. 53-67.

Larranaga, O., and D. Raczinski (1995), Caracteristicas y determinantes la pobreza y la distribucion de ingresos en Chile' (Characteristics and determinants of poverty and income distribution in Chile: diagnostics and policy lessons), unpublished manuscript, Santiago: ILADES-CIEPLAN.

Marquez, G. (2001), 'Social protection in the unemployed: programs in Latin America', in N. Lustig (ed), Shielding the Poor: Social Protection in the Developing World, Washington, DC: Brookings Institution Press/LADB, pp. 41-62.

McGarry, K., and R. Schoeni (1995), "Transfer behavior in the health and retirement study', Journal of Human Resources (supplement), 30, S184-225.

Medlin, C.A. (1996), Applying Economic Logic to Education Finance: Chile's Experiment with the Per-Student Subsidy, Santiago: ECLAC.

Mena, I., and C. Bellei (1998), 'El desafio de la calidad y la equidad en educacion' (The Challenge of Quality and Equality in Education), in C. Toloza and E. Lahera (eds), Chile en los Noventa (Chile in the Nineties), Santiago: Dolmen, pp. 353403 .

Mesa-Lago, C. (2001), 'Social assistance on pensions and health care for the poor in Latin America and the Caribbean', in N. Lustig (ed.), Shielding the Poor: Social Protection in the Developing World, Washington, DC: Brookings Institution Press/IADB, pp. 175-216.

Mezzera, J. (1993), Credito Informal: Acceso al Sistema Financiero (Informal Credit: Access to the Financial System), Geneva: Regional Employment Program for Latin America and the Caribbean, International Labour Organization.

Ministry of Education, Chile (1999), Compendio de Informacion Estadistica (Yearbook of Statistical Information), Santiago: DIPLAP-MINEDUC.

Ministry of Planning, Chile (2001a), Pobreza e Indigencia e Impacto del Gasto Social en la Calidad de Vida. Informe Ejecutivo (Poverty, Indigence and the Impact of Social Spending on Life Quality. Executive Report), Santiago: Mideplan.

Ministry of Planning, Chile (2001b), Impacto Distributivo del Gasto Social 2000. Informe Ejecutivo (Redistributive Impact of Social Spending 2000. Executive Report), Santiago: Mideplan.

Ministry of Planning, Chile (2002a), Series Encuesta CASEN. Cuadros Estadisticos 1998 (CASEN Survey Series. Statistical Tables 1998), accessed at: http://www mideplan.cl/casen $3 /$ index.html.

Ministry of Planning, Chile (2002b), Educacion Encuesta CASEN. Cuadros 
Estadisticos 1998 (Education in the CASEN Survey. Statistical Tables 1998), accessed at: http://www.mideplan.cl/casen3/index.html.

Mizala, A., and P. Romaguera (1998), Desempeno y Eleccion de Colegios (Performance and school selection) working paper no. 39, economics series, Santiago: Department of Industrial Engineering. Universidad de Chile.

Modigliani, F. (1998), 'Measuring the contribution of intergenerational transfers to total wealth', in D. Kessler and A. Masson (eds), Modelling the Accumulation and Distribution of Wealth, Oxford: Clarendon, pp. 21-52.

Moser, C. (1998), "The asset vulnerability framework: reassessing urban poverty reduction strategies', World Development, 26 (1), 1-19.

National Institute of Statistics, Chile (1998), Anuario de Demografia (Demographic Yearbook), Santiago: INE.

Oliver, M.L., and T.M. Shapiro (1995), Black Wealth/White Wealth: A New Perspective on Racial Inequality, New York: Routledge.

Rawls, J. (1999), A Theory of Justice, Cambridge, MA: Harvard University Press.

Sen, A. (1987), The Standard of Living, Cambridge: Cambridge University Press.

Sen, A. (1992), Inequality Reexamined, Cambridge, MA: Harvard University Press.

Sen, A. (1993), 'Capability and well-being', in M. Nussbaum and A. Sen (eds), The Quality of Life, Oxford: Clarendon Press, pp. 30-53.

Shapiro, T. (2001), 'The importance of assets', in T. Shapiro and E. Wolff (eds), Assets for the Poor, New York: Russell Sage, pp. 11-33.

Sherraden, M. (1991), Assets and the Poor, Armonk, NY: M.E. Sharpe.

Sherraden, M. (2001), 'Asset-building policy and programs for the poor', in T. Shapiro and E. Wolff (eds), Assets for the Poor, New York: Russell Sage, pp.302-23.

Solimano, A. (2000), 'Beyond unequal development: an overview', in A. Solimano, E. Aninat and N. Birdsall (eds), Distributive Justice and Economic Development. The Case of Chile and Developing Countries, Ann Arbor, MI: University of Michigan Press, pp. 17-36.

Spilerman, S. (2000), 'Wealth and stratification processes', Annual Review of Sociology, 26, 497-524.

Spilerman, S. (2004), 'Young couples in Israel: the impact of parental wealth on early living standards', American Journal of Sociology, 110 (1).

Stallings, B., N. Birdsall and J. Clugage (2000), 'Growth and equality: do regional patterns redeem Kutznets?', in A. Solimano, E. Aninat and N. Birdsall (eds), Distributive Justice and Economic Development. The Case of Chile and Developing Countries, Ann Arbor, MI: University of Michigan Press, pp. 98 118.

UNESCO (1999), Statistical Yearbook 1999, Paris: United Nations Educational, Scientific and Cultural Organization.

Wolff, E. (1995), 'The rich get increasingly richer: latest data on household wealth during the 1980s', in Research in Politics and Society, 5, Greenwich, CT: JAI Press, pp. 33-68.

Wolf, E. (2001), 'Recent trends in wealth ownership from 1983 to 1998', in T. Shapiro and E. Wolff (eds), Assets for the Poor, New York: Russell Sage, pp.34-73.

World Bank (2001), 'Chile poverty and income distribution in a high growth economy', documents of the World Bank, Poverty Reduction and Economic Management Sector Unit, Latin America and the Caribbean Region. 
Appendix Table 8A.I Descriptive statistics for variables in the analysis, Social Mobility Survey, 2001

\begin{tabular}{|c|c|c|c|}
\hline Variable & Mean & Standard dev. & $\mathrm{N}$ \\
\hline \multicolumn{4}{|l|}{ Husband's parents: } \\
\hline Father's education $(m)^{1}$ & 0.21 & 0.41 & 3544 \\
\hline Father's education & 6.76 & 4.79 & 2811 \\
\hline Father's occupation $(m)^{\prime}$ & 0.11 & 0.31 & 3544 \\
\hline Father's occupation ${ }^{2}$ & 31.40 & 13.03 & 3157 \\
\hline Parental wealth (In) & 2.95 & 1.36 & 3504 \\
\hline \multicolumn{4}{|l|}{ Wife's parents: } \\
\hline Father's education $(m)^{1}$ & 0.41 & 49 & 3544 \\
\hline Father's education & 6.70 & 4.75 & 2080 \\
\hline Father's occupation $(m)^{1}$ & 0.27 & 0.45 & 3544 \\
\hline Father's occupation ${ }^{2}$ & 31.17 & 13.67 & 2575 \\
\hline \multicolumn{4}{|l|}{ Respondent: } \\
\hline Number of siblings & 4.44 & 3.03 & 3539 \\
\hline Age & 46.52 & 11.77 & 3543 \\
\hline Married/cohab. vs. single & 0.88 & 0.32 & 3542 \\
\hline Cohabitating vs married & 0.11 & 0.31 & 3544 \\
\hline No. family members employed & 1.59 & 0.76 & 3470 \\
\hline Years of schooling & 9.83 & 4.43 & 3528 \\
\hline Attended public school ${ }^{3}$ & 0.79 & 0.41 & 3484 \\
\hline Attended semi-priv. school ${ }^{3}$ & 0.12 & 0.33 & 3484 \\
\hline Attended private school ${ }^{3}$ & 0.09 & 0.28 & 3484 \\
\hline Occupation status, $1995(\mathrm{~m})^{1}$ & 0.11 & 0.32 & 3544 \\
\hline Occupation status, $1995^{2}$ & 36.82 & 14.47 & 3144 \\
\hline Occupation status, $2001^{2}$ & 36.93 & 14.34 & 3490 \\
\hline Earnings (ln) & 5.30 & 0.87 & 2991 \\
\hline Household income $(\ln )$ & 5.47 & 0.91 & 3348 \\
\hline Household wealth $(\ln )$ & 3.33 & 1.15 & 3522 \\
\hline
\end{tabular}

\section{Notes:}

1. Proportion of sample with missing data.

2. ISEI status score (Ganzeboom et al, 1992).

3. Institutional type of last school attended. 
Appendix Table 8A.2 Comparison of the 2001 Social Mobility Survey with the year 2000 Chilean National Household Survey (percentage distributions)!

\begin{tabular}{|c|c|c|}
\hline & $2001 \mathrm{SMS}^{2}$ & $2000 \mathrm{CASEN}^{3}$ \\
\hline \multicolumn{3}{|l|}{ Gender: } \\
\hline Male & 100.0 & 62.9 \\
\hline Female & - & 37.1 \\
\hline \multicolumn{3}{|l|}{ Area of residence: } \\
\hline Santiago & 41.2 & 44.1 \\
\hline Rest of country & 58.8 & 45.9 \\
\hline \multicolumn{3}{|l|}{ Education: } \\
\hline $0-4$ years of schooling & 15.2 & 8.9 \\
\hline 56 & 13.7 & 8.9 \\
\hline $7-8$ & 13.8 & 12.6 \\
\hline $9-11$ & 17.9 & 16.1 \\
\hline 12 & 19.1 & 27.9 \\
\hline $13-16$ & 12.0 & 15.9 \\
\hline $17+$ & 8.0 & 9.7 \\
\hline \multicolumn{3}{|l|}{ Age: } \\
\hline $15-23$ & - & 11.9 \\
\hline $24-34$ & 18.5 & 29.8 \\
\hline 3545 & 29.7 & 30.4 \\
\hline $46-56$ & 28.9 & 18.5 \\
\hline $57-69$ & 22.9 & 8.1 \\
\hline $70+$ & - & 1.3 \\
\hline \multicolumn{3}{|l|}{ Occupation: } \\
\hline Armed forces & 1.3 & 0.5 \\
\hline Legislators, senior officials $\&$ managers & 5.8 & 6.1 \\
\hline Professionals & 7.1 & 9.0 \\
\hline Technicians and associated professions & 7.0 & 7.6 \\
\hline Clerks & 5.4 & 9.3 \\
\hline Service and shop/market sales workers & 8.3 & 14.7 \\
\hline Skilled agricultural \& fishery workers & 2.4 & 6.0 \\
\hline Craft \& related trades workers & 27.7 & 15.0 \\
\hline Plant \& machine operators/assemblers & 16.0 & 9.0 \\
\hline Elementary occupations & 18.8 & 22.5 \\
\hline \multicolumn{3}{|l|}{ Earnings (pesos/month) } \\
\hline Less than 120000 & 32.2 & 37.5 \\
\hline $120000-210000$ & 29.5 & 27.2 \\
\hline $210000-390000$ & 19.9 & 18.8 \\
\hline $390000-1000000$ & 16.9 & 12.2 \\
\hline More than 1000000 & 2.5 & 4.3 \\
\hline $\mathrm{N}$ & 3544 & 182885 \\
\hline
\end{tabular}


Notes:

1. CASEN (Encuesta de Caracterizacion Socioeconomica Nacional) is a national household survey, conducted every two years by the Chilean Ministry of Planning. The year 2000 version contains 252748 cases.

2. Percentages weighted to correct for stratification. Representation differences from CASEN are due to the sampling design: the SMS survey was restricted to male heads of household in the age range 24-69.

3. CASEN data refer to the economically active population aged 15 and older. 